\begin{tabular}{lll} 
KULTURA & $\begin{array}{l}\text { POLSKA A KADEMIA NAUK } \\
\text { KOMITET SOCJOLOGII }\end{array}$ & ISSN 0023-5172 \\
i & $\begin{array}{l}\text { INSTYTUT ST UIÓW POLITYCZNYCH } \\
\text { SPOLECLENSTWO nr 4 }\end{array}$ & WYMIARY POLITYCZNOŚCI \\
\hline
\end{tabular}

BARTOSZ MIKA

Uniwersytet Gdański

\title{
DOBRO WSPÓLNE OKIEM SOCJOLOGA - KILKA UWAG PORZĄDKUJĄCYCH
}

Dobro wspólne - pojęcie wywodzące się od Arystotelesa — stanowi jedno z nośnych haseł nauk społecznych i humanistycznych. Przeważnie używane jest przez filozofów, przedstawicieli społecznej nauki Kościoła katolickiego (za sprawą spuścizny Tomasza z Akwinu), prawoznawców oraz ekonomistów. Kiedy pojawia się w socjologii, to najczęściej jako pojęcie pomocnicze, kalka pojęciowa lub hasło. Nawet w tekstach tytularnie odnoszących się do tego zagadnienia - na przykład w opracowaniu Danuty Walczak-Duraj (2014) - można znaleźć jedynie pośrednie, mediujące określenia interesującego nas pojęcia ${ }^{1}$. Przyjąć wręcz można, że socjologia doskonale obywa się bez tego terminu, konstruując swój język z jego pominięciem. Celem tych rozważań nie jest zmiana stanu rzeczy, lecz pewne uporządkowanie pojęć na potrzeby socjologii. Potrzebę tę wiążę przede wszystkim z renesanesem lub, jak chce David Bollier (2014), „odkrywaniem na nowo” zagadnień związanych z dobrem wspólnym w naukach siostrzanych socjologii. Ponieważ siostrzana miłość bywa zaborcza, a mówiąc mniej metaforycznie - socjologia współczesna cierpi z powodu kolonizacji jej języka przez nauki z nią graniczące, sądzę, że warto pewne sprawy uporządkować i wyjaśnić. Wskażę przy tym, w jakich okolicznościach nauki pokrewne zbaczają na teren socjologii i jak, w związku z tym, mogłyby wykorzystać jej dorobek.

Adres do korespondencji: bartosz.mika@ug.edu.pl

${ }^{1} \mathrm{~W}$ przytoczonym tekście autorka formułuje zdania zawierające termin „dobro wspólne” tak, jakby pojęcie było powszechnie znane, a jego definicja podzielana i uznawana przez środowisko naukowe. Wydaje się jednak, że takie — entymematyczne, jeśli można tak powiedzieć — jego potraktowanie, choć nieodosobnione, jest niedopatrzeniem. 


\section{DOBRO WSPÓLNE}

„Dobro wspólne” jest jednym z tych stale obecnych w humanistyce pojęć, które rozumiane są bardzo różnie. Można wyodrębnić trzy nierozłączne sposoby jego definiowania.

(1) Zgodnie $z$ tradycjami filozoficznymi sięgającymi Platona (pytanie o dobro), Arystotelesa (wspólnota) i Tomasza z Akwinu (dobro wspólne) - jako postulat lub koncepcja optymalnego społeczeństwa.

(2) Dobro wspólne można też rozumieć rzeczowo, jako dobro lub dobra wspólne (the commons), co pierwotnie odnosiło się do zasobów materialnych, takich jak pastwiska, łowiska, zasoby lasów deszczowych, przestrzeń publiczna itp., a współcześnie także do wiedzy (Ratajczak 2015), dóbr cyfrowych (Hofmokl 2009) czy kodów językowych (Bollier 2014).

(3) Jeszcze inne rozumienie dobra wspólnego wiąże się z szeroko pojmowanymi pozytywnymi wytworami życia społecznego powstającymi w toku codziennych działań, systematycznego budowania wspólnot, organizacji i instytucji. Przy pobieżnym oglądzie ten sposób patrzenia na dobro wspólne wydaje się bliski pierwszemu. Jednak różnica jest istotna; aksjologiczne pojmowanie dobra wspólnego może być scharakteryzowane jako próba odpowiedzi na pytanie: jakie powinno być społeczeństwo i jego mechanizmy, natomiast rozumienie go jako efekt życia społecznego odnosi się raczej do tego, jak przebiega konstruowanie zdolnego do homeostazy społeczeństwa ${ }^{2}$ (i/lub czym ono jest).

Ponieważ wszystkie trzy rozumienia nie są rozłączne ani ścisłe ${ }^{3}$, niezwykle trudno wskazać granicę przebiegającą między aksjologicznie i ontologicznie pojmowanym dobrem wspólnym, między substancjalnym i niesubstancjalnym jego rozumieniem (Walczak-Duraj 2014). Celem tych rozważań nie będzie jednak podsuwanie rozstrzygnięć lub formułowanie jednoznacznej definicji, lecz - ze względu na rażące niekiedy zapoznawanie dorobku socjologii (zwłaszcza klasycznej) zarówno w rzeczowym, jak i wspólnotowym rozumieniu dobra wspólnego - próba uczynienia debaty wokół dobra wspólnego bardziej otwartą na kwestie socjologiczne.

${ }^{2}$ Często pytanie to odnosi się do społecznych fundamentów gospodarki, a w skrajnych ujęciach używa się określenia „produkcja życia społecznego”.

${ }^{3}$ Krystian Szadkowski (2015) proponuje inną typologię rozumienia dobra wspólnego: „dobro wspólne”, „dobra wspólne” oraz „to, co wspólne”. Pomijając w tym miejscu niefortunność semantyczną takiego doboru pojęć należy wskazać, że przyjęte przez Szadkowskiego rozumienie odnosi się do określonej tradycji opisu dobra wspólnego, którą autor określa jako: „materialistyczne dobro wspólne”. Dla nas ważne jest to, że wszystkie wymienione poziomy rozumienia pojęcia zawierają ważny komponent socjologiczny, co powoduje, że granica między nimi jest nieostra. 


\section{DOBRO WSPÓLNE W EKONOMII}

W ortodoksyjnej perspektywie ekonomicznej rozważa się dobro wspólne jako kategorię rzeczową, wskazując na ekonomiczną przewagę określonych form własności. Za przykład niech służy obfity dorobek teorii praw własnoś ci, w którym zwraca się szczególną uwagę na problem nadużycia dóbr wspólnych (często utożsamianych $z$ dobrami publicznymi). Jednocześnie perspektywa ekonomiczna - zwłaszcza neoinstytucjonalna - każe widzieć w dobrach wspólnych otoczenie społeczne transakcji, podkreślając jego dwie funkcje: pozytywne warunki działalności gospodarczej (takie jak stabilny porządek prawny, moralność podatkowa, kapitał ludzki, a na obrzeżach ekonomii również kapitał społeczny itp.) oraz obszar eksternalizacji kosztów. Inaczej mówiąc, większość ekonomistów zgodzi się, że działalność gospodarcza jest osadzona w społeczeństwie (Granovetter 1985), a przez to im stabilniejszy porządek publiczno-prawno-społeczny, tym łatwiejsza działalność ekonomiczna, a także że otoczenie rynku stanowi dla niego „zewnętrze”, w które można (co nie oznacza, że należy) eksternalizować negatywne efekty działalności gospodarczej.

Jest jeszcze trzecia możliwość, która odnosi się do przyswajania pozytywnych efektów zewnętrznych wytworzonych przez wspólnoty zorganizowane wokół dóbr wspólnych. Inaczej mówiąc, chodzi o zjawisko określane w literaturze mianem „nowe grodzenia”, polegające na prywatyzowaniu korzyści generowanych przez publiczne lub wspólne zarządzanie własnością. Okazją do powstawania tak rozumianych dóbr wspólnych jest bogaty świat internetu, a zwłaszcza opisana przez Yochai Benklera (2008) produkcja partnerska.

Formułując to pojęcie amerykański badacz odniósł się do słynnego teorematu Ronalda Coase'a (1937) dotyczącego kosztów transakcyjnych. Ekonomista ten doszedł do wniosku, że rynek tylko wówczas będzie efektywnym regulatorem działań gospodarczych, jeśli koszt transakcji rynkowej będzie niższy niż koszty organizacyjne niezbędne do zintegrowania danej transakcji w strukturze firmy. Na tej podstawie Benkler (2008) argumentował, że powstanie dobra ekonomicznego możliwe jest dzięki transakcjom rynkowym lub w strukturze organizacyjnej firmy. Dodał przy tym trzecią możliwość — powstanie dobra poza rynkiem i organizacją - wynik nieodpłatnej, opartej na pasji aktywności dobrowolnych współpracowników. Dotyczy to zwłaszcza dóbr informacyjnych i symbolicznych, których specyfiką jest nierywalizacyjna konsumpcja i trudność w kontroli użytkowania. Ponadto konsumpcja dóbr informacyjnych (zarówno na potrzeby wytwarzania kolejnych dóbr, jak i w celach osobistych) nie wywołuje negatywnych efektów zewnętrznych, a często, nawet jeśli jest nieuprawniona, wytwarza efekty pozytywne (Lemley 2004). New commons, jak czasem określa się niemające materialnej postaci dobra wspólne, sprawiają ekonomii głównego nurtu trudności interpretacyjne nie tylko ze względu na ich nierywalizacyjność. Również ograniczenie kontroli dostępu do dobra skłania do pytań, 
czy tego rodzaju zasoby mogą być nazwane własnością ${ }^{4}$ (Hofmokl 2009). Obszary zainteresowania ekonomii zagadnieniem dóbr wspólnych można zobrazować za pomocą schematu:

Schemat 1

Ekonomiczna rola dóbr wspólnych

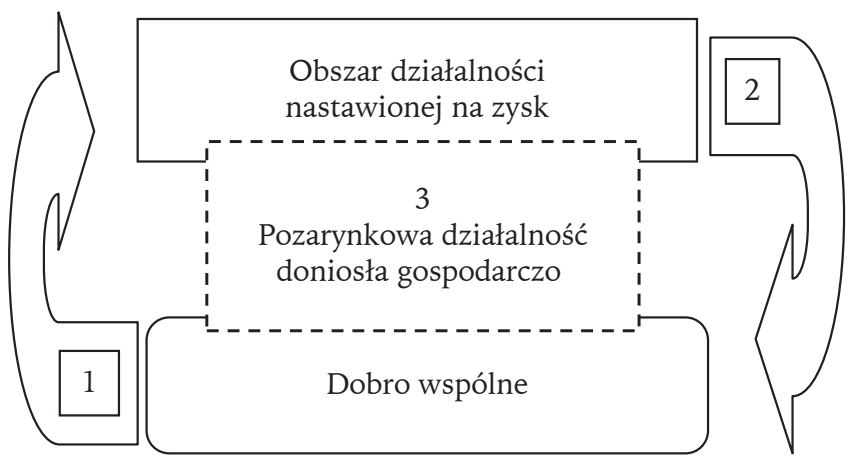

1. Przyswajanie pozytywnych efektów działania wspólnoty, np. zaufania, uczciwości, stabilnego systemu prawnego.

2. Eksternalizacja kosztów, np. zanieczysczeń.

3. Pozarynkowa aktywność doniosła dla rynku, np. wspólnoty open source, praca domowa.

Źródło: opracownie własne.

Punktem trzecim zajmiemy się $\mathrm{w}$ dalszej części pracy. Niewiele do tej pory powiedziano o zarządzaniu dobrem wspólnym. Autorką, która szczególnie konsekwentnie zwraca uwagę na nierywalizacyjny (podzielny) oraz trudny w kontroli charakter dóbr wspólnych i jednocześnie poświęciła większość swojej akademickiej aktywności na badanie konkretnych organizacji zarządzania dobrami wspólnymi jest Elinor Ostrom (1990). Włożyła ona wiele wysiłku w polemikę i rozwinięcie koncepcji wspólnego użytkowania zasobów, z jednej strony krytykując formalizm podejść ekonomicznych utrudniający dostrzeżenie innych form zarządzania własnością niż prywatne lub publiczne, z drugiej wskazując ograniczenia tradycyjnej teorii gier, a wraz z nią osławionej tragedii wspólnego pastwiska (zob. Hardin 1968). Dowiodła, że przy zachowaniu określonych warunków brzegowych, takich jak znane granice wspólnoty korzystającej z dobra, możliwość tworzenia i modyfikowania reguł, monitorowania ich działań oraz egzekwowania sankcji wobec gapowiczów, wspólnoty powstałe wokół dóbr wspólnej puli radzą sobie lepiej z zarządzaniem wspólną własnością niż państwo lub prywatny właściciel (zob. Ostrom 1990).

${ }^{4}$ Wszak składnikiem definicyjnym zarówno prawniczej, jak i występującej w teorii praw własności koncepcji własności jest możliwość kontroli nad rozporządzanym dobrem. W omawianym przypadku taka kontrola nie istnieje lub wymaga znacznych nakładów.

Można dodać, że pytanie o własnościowy charakter praw własności intelektualnej daje się łatwo rozstrzygnąć, gdy wyjdziemy poza formalnoprawne i sztywne ekonomiczne rozumienie własności (zob. Mika 2016). 
Ostrom i wielu innym podejmującym problem dóbr wspólnych można zarzucić, że są wystawieni na ryzyko językowej, a czasem też teoretycznej nieścisłości. Otóż pojęcie dobra wspólnego zawiera milczącą przesłankę istnienia wspólnej własności, podczas gdy fakt ten należy dopiero wykazać. Ostrom i Hess (2003) pozornie rozwiązują ten problem twierdząc, że czym innym jest obiekt własności, a czym innym ukonstytuowany wokół niego system własności. Trudno nie zgodzić się z takim założeniem, już bowiem Max Weber (2002) wskazywał, że to nie przedmiot własności nosi w sobie ekonomiczną treść, lecz stosunki społeczne, jakie się z nim wiążą, określają jego użycie jako narzędzia, dobra inwestycyjnego lub konsumpcyjnego itp. ${ }^{5}$ Według opisywanego podejścia cechy obiektu, takie jak: (ograniczona) podzielność i trudność wykluczenia użytkowników, niejako substancjalnie określają jego wspólnotowy charakter. Dochodzi więc do sprzeczności - autorki odróżniają system własności od obiektu własności jednocześnie utrzymując, że cechy obiektu określają jego charakter i - co za tym idzie - powstające wokół niego stosunki własnościowe ${ }^{6}$. Tymczasem z socjologicznego lub, mówiąc bardziej precyzyjnie, socjoekonomicznego punktu widzenia przedmiot jako taki nie tylko nie determinuje systemu własności, ale właściwie nic o nim nie mówi. Dopiero określony układ relacji społecznych wokół danego przedmiotu oraz jego naukowe rozpoznanie pozwalają mówić o wspólnej lub jakiejkolwiek innej własności. Odpowiedzialność za tę trudność semantyczno-teoretyczną ${ }^{7}$ ponosi krytykowany przez Ostrom i Hess (2003) prawno-ekonomiczny dyskurs dotyczący własności, który mimo wszystko pozostaje dla nich głównym punktem odniesienia.

Inny kłopot semantyczny ujawniający się, gdy sięgamy po termin „dobro wspólne”, dotyczy pierwszego jego członu. Rozumiany wąsko ekonomicznie oznacza wytwór procesów produkcyjnych, dar przyrody lub historii, obiekt transakcji rynkowej (przynajmniej potencjalnie) lub doniosłe dla niej otoczenie. Inaczej mówiąc, dobrem w perspektywie gospodarki jest zasób, który może zostać uruchomiony w celu pomnażania wartości, jest obiektem konsumpcji lub stanowi źródło efektów zewnętrznych (tudzież obszar usuwania na zewnątrz negatywnych efektów powstałych $\mathrm{w}$ organizacji).

Warto $\mathrm{w}$ tym miejscu podkreślić błąd często występujący w literaturze przedmiotu: czym innym jest rozstrzygnięcie, czy własność danego obiektu ma

${ }^{5}$ Weber odróżnia na przykład konia użytego w charakterze zwierzęcia pociągowego na roli od tego samego konia wykorzystanego w celach rekreacyjnych.

${ }^{6}$ Współczesny system własności intelektualnej dowodzi, że nierywalizacyjne i trudne w wykluczeniu dobro, takie jak (hasłowo rzecz ujmując) informacja, może być wydajnie „ogrodzone” i traktowane jako prywatne.

${ }^{7}$ Dodajmy może, że w języku oryginału trudność semantyczna nie jest tak doniosła, gdyż Hess i Ostrom piszą o common-pool resource, odróżniając je od common-property resource. Nadmienić też trzeba, że wspomniana trudność nie rzutuje na jakość empirycznych dokonań laureatki Nagrody Banku Szwecji im. Alfreda Nobla, w których zawsze uwzględniany był konkretny układ stosunków własnościowych. 
charakter indywidualny czy zbiorowy, czym innym zaś określenie prywatnowłasnościowego lub osobistowłasnościowego sposobu korzystania z dobra. Obiekt może być własnością zamkniętej wspólnoty (jak wiele z tych opisywanych przez Ostrom), podlegać jej normom i przynosić jej członkom prywatnowłasnościowy dochód ${ }^{8}$ lub może stanowić obiekt ekskluzywnej konsumpcji (Ostrom nazywa tego rodzaju dobra klubowymi) bądź otwartego dostępu. Innymi słowy, własność może służyć utrzymaniu członków wspólnoty lub ich osobistej konsumpcji.

Odrębną kwestią jest, czy własność danego obiektu ma charakter indywidualny czy też zbiorowy. Mówiąc prościej, chodzi o to, ilu jest właścicieli. Można przewrotnie stwierdzić, że współczesna gospodarka w znacznej części opiera się na własności zbiorowej (tak zwanej publicznej ofercie i wymianie odbywającej się na rynkach finansowych [giełdach]). Hess i Ostrom (2003) słusznie zarzucają ekonomii ortodoksyjnej doktrynerskie rozróżnienie własności jedynie na prywatną i publiczną. Empiryczny świat dostarcza dowodów, że życie gospodarcze rzadko opiera się na indywidualnej własności prywatnej, raczej premiując różnego rodzaju zbiorowe formy własności. Oczywiście należy zachować wszelkie proporcje; korporacja o rozproszonym akcjonariacie to pod wieloma względami zupełnie inny podmiot niż lokalna społeczność wiejska wspólnie zarządzająca areałem upraw ${ }^{9}$. Chodzi tu jedynie o wskazanie nietożsamości kategorii prywatnej i indywidualnej własności oraz nierozłączności prywatnej i kolektywnej własności.

Ostatecznie więc można powiedzieć, że ekonomiczna analiza dobra wspólnego odnosi się przede wszystkim do korzystania z obiektu własności (rzeczowego lub nierzeczowego) i zarządzania nim w określony sposób. Jest to konstatacja ważka z uwagi na kryjący się za nią nominalizm zbiorowości społecznych (Szczurkiewicz 1969). Beneficjenci dobra wspólnego są bowiem pojmowani jako agregat jednostek połączonych podobnym usytuowaniem wobec obiektu własności ${ }^{10}$ - kolektyw, który korzysta $z$ określonego dobra, stanowi zatem wypadkową indywidualnych wyborów. Wspólnotowy charakter życia społecznego jest sprowadzony do możliwości wzajemnej koordynacji działań wysoce autonomicznych podmiotów, $\mathrm{z}$ których każdy jest $\mathrm{w}$ określonym stopniu racjo-

\footnotetext{
${ }^{8} \mathrm{Na}$ przykład rybacy ustalają zasady połowu tak, aby łowisko miało możliwość spontanicznej regeneracji zasobów ryb, a nie po to, aby wszyscy mogli z niego korzystać, lub nie po to, aby populacja danej ryby nie wyginęła, lecz aby zapewnić sobie prywatny, stabilny i relatywnie pewny przychód.

${ }^{9}$ Różnica może polegać choćby na wysokości uzyskiwanego dochodu, sposobach i czasie jego podziału (np. czy zysk jest w całości dzielony między podmioty indywidualne czy jakaś jego część pozostaje w dyspozycji wspólnoty), zasięgu rynku, w którym uczestniczy podmiot, procedurach podejmowania wspólnych decyzji, możliwości stałego nadzoru nad obiektem własności, a także na celach organizacji (celem korporacji jest ostatecznie zysk, spółdzielnia czy kooperatywa może a czasem z powodów prawnych musi - na pierwszym miejscu stawiać cele społeczne).

${ }^{10} \mathrm{~W}$ przypadku common pool-resources najczęściej geograficznie.
} 
nalny ${ }^{11}$. Z dobra wspólnego korzystają jednostki połączone przede wszystkim stosunkiem do tegoż dobra wspólnego.

\section{DOBRO WSPÓLNE A WSPÓLNOTA}

W niektórych podejściach budowanych na gruncie filozofii społecznej dobro wspólnoty określane jest jako dobro społeczności, a nie sumy jednostek, z których się ona składa. Przyjęcie takiego punktu widzenia wymaga realistycznego lub modalistyczno-apriorycznego definiowania grupy (Szczurkiewicz 1969). Zakłada się, że człowiek jako podmiot życia społecznego jako jedyny posiada własne, autonomiczne życie wewnętrzne, jednocześnie jednak jest bytem, którego warunkiem antropo- i ontogenzy (Marody, Giza-Poleszczuk 2004) jest zakorzenienie w życiu społecznym. Innymi słowy: nie ma człowieka z jego specyficznymi cechami w oderwaniu od społeczeństwa. Dopiero w toku socjalizacji lub - jak piszą Mirosława Marody i Anna Giza-Poleszczuk (2004) — uspołecznienia jednostka nabywa cech charakterystycznych dla umysłu ludzkiego.

\section{Dobrowspólne - liberalizm}

Michael Novak (1998), próbując pogodzić katolicką tradycję Akwinaty z liberalizmem, wychodzi ze zbliżonych założeń ontologicznych i podkreśla konsekwentnie społeczny charakter życia ludzkiego. Krytykuje obiegowe założenie liberalizmu mówiące, że dobro wspólne to wynik niezamierzonych, przypadkowych działań jednostek dążących do indywidualnych celów, i zwraca uwagę na znaczenie porządku normatywnego, w którego obrębie dążenia te są formułowane i realizowane. Zgodnie z liberalną tradycją Novak podkreśla napięcie między rządem - czy szerzej: sferą publiczną - a społeczeństwem obywatelskim. Dobro wspólne nigdy - w nowoczesnym państwie - nie może być gwarantowane tylko przez państwo, wymaga ono aktywnego, pluralistycznego społeczeństwa złożonego z wolnych i świadomych swych obowiązków obywateli. Warunkiem zaś ich istnienia jest stabilny porządek moralny i społeczny ${ }^{12}$.

Novak bardzo trafnie zastrzega, że dobro wspólne to pojęcie o genezie antycznej (a więc przednowoczesnej), co pozwala mu dostrzec historyczność tej kategorii. „Starając się uściślić termin «dobro wspólne», przekonujemy się jednak, że mowa o konkretnym stanie rzeczy — o dobru wspólnym kon k re t n ej wspólnoty w konkretnym momencie [podkr. oryg.]" (Novak 1998, s. 105).

11 Oczywiście określenie tego, co dokładnie oznacza „racjonalność podmiotu”, pozostaje sprawą otwartą.

12 Na gruncie takiej diagnozy łatwo „przerzucać mosty” między obligacjami moralnymi a wymogami gospodarki, co we współczesnej socjologii przybiera postać mody na pojęcia takie jak „kapitał społeczny”, „kapitał zaufania”. Także Novak (1998, s. 142) przyjmuję tę perspektywę, pisząc: „rynek opiera się na zaufaniu. Zaufanie jest zakorzenione w dziedzinie moralnej, w prawie, obyczaju i tradycji". 
Obserwacja ta prowadzi autora do wniosku o radykalnej zmianie znaczenia pojęcia dobra wspólnego: $z$ celu działania wspólnoty — jak było ono pojmowane $\mathrm{w}$ okresie przednowoczenym - na pewien rodzaj porządku społecznego pomyślanego tak, aby dać maksymalnie wiele wolności wolnym osobom ${ }^{13}$. W liberalnym podejściu Novaka (1998, s. 109) dobro wspólne to korzyści płynące $z$ dobrowolnej współpracy gwarantowane przez porządek zapewniający koordynację zindywidualizowanych celów wolnych podmiotów.

Socjologiczna interpretacja przedstawionych tu hasłowo rozważań Novaka ujawnia kilka istotnych kwestii. Po pierwsze, to co zrazu wydawało się podejściem co najmniej modalistyczno-apriorycznym, trafia na problem aktywizmu i subiektywizmu osoby i sugeruje przejście na pozycję fikcjalizmu lub nawet nominalizmu (Szczurkiewicz 1969). Należy zakładać, że Michael Novak celowo nie podejmuje tego zagadnienia - ograniczając się do ogólnych stwierdzeń o społecznej naturze życia ludzkiego - aby nie podważać postulowanej przez niego bliskości konsekwentnego liberalizmu i katolickiego kolektywizmu. Ten z kolei opiera się na idei praw naturalnych, które również nie znajdują u Novaka satysfakcjonującego uzasadnienia. Mam na myśli szczególne znaczenie praw przyrodzonych - lub boskich — dla kształtu społeczeństwa i samego faktu jego zaistnienia. Nie jest to problem czysto teologiczny, gdyż w wywodzie Novaka można znaleźć wiele określeń tautologicznych i niekonsekwencji w opisie związków przyczynowo-skutkowych. Pisze on na przykład: „rynek jest zatem społecznym urządzeniem służącym do realizacji dobra wspólnego” (Novak 1998, s. 146). Jest więc rynek procedurą realizacji dobra wspólnego, ale jednocześnie - skoro „rynek opiera się na zaufaniu” (Novak 1998, s. 142) — jest także efektem istnienia pewnych norm społecznych. Czy zatem rynek może istnieć dzięki społecznemu porządkowi normatywnemu czy jest jego wytwórcą? Nie wiemy. Jak ów porządek ma się do dobra wspólnego - także trudno dociekać na podstawie tego, co expressis verbis pisze Novak. Ogólnie można powiedzieć, że relacje między tym, co jest przyczyną powstania dobra wspólnego, a co jego skutkiem, są trudne do zdefiniowania.

Osobną sprawą jest apoteoza czy wręcz absolutyzacja rynku i liberalnej demokracji - zwłaszcza amerykańskiej - która zaskakuje wobec wyraźnego uznania historycznego charakteru omawianego pojęcia ${ }^{14}$. Dziwi zwłaszcza fakt, że autor, który z taką mocą i przekonaniem mówi o historycznym uwikłaniu dobra wspólnego, naiwnie rozprawia o wolności, zupełnie nie dostrzegając

\footnotetext{
13 Pojęcie osoby jest u Novaka ważne, wiąże się bowiem z katolicką filozofią przypisującą podmiotowi wolność wyboru i świadomość podejmowania własnych decyzji oraz odpowiedzialność za własne czyny.

${ }^{14}$ Niektóre fragmenty dotyczące socjalizującej roli rynku jako „nauczyciela moralności” (tytuł jednego z podparagrafów rozdziału III) w świetle doświadczeń ostatnich dwóch dekad brzmią wręcz niedorzecznie, a przypisywanie patentom czy ogólnie ochronie praw własności intelektualnej (Novak 1998, s. 147) roli promotora kreatywności nijak ma się do aktualnych debat na ten temat (zob. Szahaj 2014).
} 
jej powiązania z konkretną historyczną formą uspołecznienia (Marody, Giza-Poleszczuk 2004) oraz konsekwencjami, do jakich takie społeczne osadzenie problematyki wolności prowadzi (zob. zwłaszcza Kochan 2004).

Co więcej, przeciwstawiając przednowoczesną formę dobra wspólnego opartą na wyznaczeniu celów i formę nowoczesną polegającą na tworzeniu procedur, Novak w uproszczony sposób powiela bogate tradycje socjologii. Znaleźć tu można echa klasycznego podziału Durkheima na solidarność organiczną i mechaniczną, znany powszechnie podział Tönniesa na wspólnoty i stowarzyszenia, Weberowską racjonalizację czy nawet Foucaultowską analizę przejścia od władzy autorytarnej do władzy dyscyplinującej. Ze szkodą dla całego wywodu tradycje te pozostają nieodnotowane i niewykorzystane.

\section{Dobrowspólne jako komunizm}

Punkt widzenia Michela Foucaulta stanowi istotny składnik zdecydowanie odmiennej koncepcji dobra wspólnego, którą proponują włoscy filozofowie z kręgu marksizmu autonomicznego: Michael Hardt i Antonio Negri. W tej perspektywie dobro wspólne to: „po pierwsze, wspólne bogactwo materialnego świata [...] o którym wiele klasycznych europejskich tekstów politycznych głosiło, że jest dziedzictwem całej ludzkości [...]. Za dobro wspólne uważamy także, co ważniejsze - piszą Hardt i Negri (2012, s. 76) - te rezultaty społecznej produkcji, które są niezbędne dla społecznych interakcji oraz dalszej produkcji [podkr. - B.M.]”. Dobro wspólne stanowi w tej koncepcji efekt pracy biopolitycznej podejmowanej przez wielość. Owa produkcja biopolityczna, będąca zmodyfikowaną formą pojęcia biopolityki ukutego przez Foucaulta, „zmienia gospodarcze centrum grawitacji z produkcji materialnych towarów na relacje społeczne, zacierając [...] podział między produkcją i reprodukcją" (Hardt, Negri 2012, s. 236). Dlatego Kazimierz Krzysztofek (2012, s. 15) trawestując Maurizia Lazzarato, innego reprezentanta postoperaizmu, stwierdził: „zaciera się granica między czasem wolnym a pracą, tak zmianie ulega relacja między kapitałem a pracą na rzecz relacji kapitał-życie, bo życie kreuje twórczość w codziennych aktach: pamięć, wiedza, ego, kultura, seks. Życie po prostu wytwarza złoża "społecznego software'u», z którego czerpie się "pełną myszką", przekształcając te zasoby w kapitał”. Zdanie to dobrze oddaje ogólny pogląd autonomistów na relacje między tym, co społeczne, a gospodarką. Koherentna $z$ tym poglądem jest również koncepcja dobra wspólnego jako efektu kooperacji międzyludzkiej opartej głównie na pracy niematerialnej i wiedzy. Dobro wspólne to - jak napisał wierny czytelnik i tłumacz Hardta i Negriego (Szadkowski 2015, s. 230) — „przede wszystkim akt uwspólniania, czyli odsłaniania wspólnego charakteru elementów zbiorowo przeżywanej rzeczywistości”. Akt ten przeciwstawiony jest kapitałowi (lub bardziej ogólnie „Imperium" - zob. Hardt, Negri 2005) rozumianemu jako siła zewnętrzna i pasożytująca na „żywej pracy”. Ostatecznie więc dobro wspólne w rozumieniu 
Hardta i Negriego to zreinterpretowana idea komunizmu opartego na samorozwoju i samookreśleniu uwolnionej spod jarzma kapitału pracy biopolitycznej wykonywanej przez, będącą jednością części, wielość.

„Wielość” jest pojęciem interesującym socjologicznie, gdyż — jak napisał Norbert Elias w pierwszych słowach Społeczeństwa jednostek (2008, s. 1): „relacja wi elości jednostek do pojedynczej osoby, nazywanej «jednostką", oraz pojedynczej osoby do większej ich liczby nie jest dziś bynajmniej rzeczą jasną [podkr. - B.M.]”. Można powiedzieć, że wytykane przez Eliasa przyzwyczajenia zadomowione $\mathrm{w}$ myśleniu potocznym i akademickim nakazują traktować to zdanie jako aktualne. Zaproponowane przez przywoływanych wyżej filozofów marksistowskich pojęcie wielości stanowi próbę wyjścia na przeciw tym trudnościom. Rozumieć je można jako: „mnogość działających razem pojedynczości, klas[ę] produktywnych podmiotów złączonych powszechnym doświadczeniem wyzysku, "rojową inteligencję» i głośn[e] żądanie demokracji" (Hardt, Negri 2012, s. 45, jak piszą polscy tłumacze tej pracy: wielość to ontologiczna władza łącząca w sobie to, co jednostkowe i społeczne). Inny filozof $z$ tego samego kręgu intelektualnego Gigi Roggero (2011, s. 80) w analogicznym kontekście mówi o wolności ucieleśnionej w relacji między pojedynczością a dobrem wspólnym, a więc o wolności we wspólnocie złożonej z części.

Kategoria wielości jest zatem $z$ gruntu socjologiczna i sugeruje wyczulenie autorów z kręgu włoskiego postoperaizmu ${ }^{15}$ na zagadnienia społeczne. Niestety, jak głosi znane powiedzenie, jedna jaskółka wiosny nie czyni, a i ta konkretna jaskółka okazuje się zgoła innym ptakiem ${ }^{16}$.

Przede wszystkim trzeba podkreślić, że proponowana przez Negriego i Hardta wizja ładu społecznego nosi wszelkie znamiona - jak powiadał Szczurkiewicz (1969) - metafizyki zakapturzonej, obciążonej wieloznacznością i przedwczesnymi uogólnieniami. Zdaniem Szczurkiewicza ten rodzaj rozumowania wystawia badacza na ryzyko ześlizgnięć w kierunku myślenia potocznego. Żeby nie być gołosłownym: Hardt i Negri (2012, s. 265) odkrywczo stwierdzają, że rodzice dbają bardziej o swoje dzieci niż o rówieśników, „kiedy [...] podejmowane w szkole decyzje stawiają dobro ich dziecka przeciwko dobru innych lub całej wspólnoty, wielu rodziców wysuwa pod przykrywką cnoty argumenty o bezwzględnie antyspołecznym charakterze". Znamienne, że autorzy nie wspominaja, jaka jest ich zdaniem geneza owego „doboru krewniaczego" ani pod jakimi warunkami jest on zagrożeniem dla dobra wspólnego.

15 Posługuję się tu pojęciem lokującym tę tradycję we Włoszech, choć trzeba podkreślić, że współcześnie wykracza ona daleko poza Półwysep Apeniński.

16 Ponieważ pojęcie wielości zostało poddane krytyce w innym miejscu (zob. Mika 2013), tu chcę jedynie podkreślić jej powierzchowny — jeśli chodzi o socjologiczną treść — sens. 
Inny błąd uwidacznia się w opinii, że: „ekskluzywna natura modelu rodzinnego, który niesie ze sobą nieuchronnie wszystkie swoje wewnętrzne hierarchie, normy genderowe i heteronormatywność [...] jest dowodem braku wolności do tworzenia i eksperymentowania $z$ alternatywnymi relacjami społecznymi oraz nie-rodzinnymi strukturami pokrewieństwa" (Hardt, Negri 2012, s. 264). Autorzy krytykują tu — dodajmy, że trafnie — kulturowy porządek płci (Connell 1987, 1995), a więc hegemoniczny model rodziny, zapominając zupełnie, że w Wielkiej Brytanii już w latach dziewięćdziesiątych XX wieku jedynie co czwarte gospodarstwo domowe złożone było z małżeństwa $z$ co najmniej jednym dzieckiem (zob. Giddens 2006). Ujmując sprawę inaczej: co innego hegemoniczny wzorzec normatywny, a co innego empiryczne zróżnicowanie modeli życia rodzinnego, o czym wie każdy socjolog, a co najwyraźniej umyka omawianym filozofom.

Kategoria wielości naraża również autorów na zarzut monokauzalizmu, ponieważ jedynym czynnikiem łączącym członków wielości jest ich stosunek do kapitału. Pisząc: „wielość nadaje pojęciu proletariatu pełnie znaczenia obejmując wszystkich tych, którzy pracują i wytwarzają pod jarzmem kapitału" (Hardt, Negri 2004, s. 107), czynili z tej kategorii byt cokolwiek efemeryczny i właściwie niemożliwy do socjologicznej interpretacji (nie wiadomo bowiem, czy należy ją traktować jako kategorię statystyczną, socjologiczną czy społeczną; zob. Sztompka 2012).

Nie przypadkiem odwoływałem się tutaj do popularnych podręczników socjologii - wymienione trudności stanowią socjologiczne abecadło. Hardt i Negri zabezpieczają się jednak przed taką krytyką, przenosząc empiryczny sens wielości w przyszłość. Jak napisał Mikołaj Ratajczak (2010, s. 167): „postaram się [...] zachować funkcjonujące w pismach autorów Multitude rozróżnienie na wielość sub specie aeternitatis (wielość jako abstrakcyjną ideę i jako nowe ujęcie relacji jednego do wielu) oraz na wielość jako podmiot przemian historycznych, twór konkretnych procesów produkcji i aktywności politycznej”. Autorzy tejże Multitude uściślają: „ta pierwsza wielość jest ontologiczna i nie bylibyśmy w stanie wyobrazić sobie bez niej naszego bytu społecznego. Druga jest wielością historyczną, albo inaczej mówiąc, jeszcze-nie wielością. Ta wielość jeszcze nigdy nie zaistniała" (Hardt, Negri 2004, s. 218). Inaczej mówiąc, druga wielość ma charakter profetyczny i domniemany, pierwsza natomiast to nic innego jak ogólna charakterystyka więzi społecznych.

\section{DOBRO WSPÓLNE A WIĘZI SPOŁECZNE}

Wracamy zatem do punktu wyjścia i pytania o socjologiczny sens dobra wspólnego. Jak wynika z powyższych rozważań, można je traktować w trojaki sposób: (1) jako projekt dobrego społeczeństwa, (2) jako dar natury lub przyrody ludzkiej będący w zbiorowej dyspozycji jednostek oraz (3) jako ponadjednostkowe efekty istnienia wspólnoty. Trzecie rozumienie jest najbardziej socjo- 
logicznie interesujące ${ }^{17}$, pozwala jednocześnie udzielić odpowiedzi na pytanie, dlaczego pojęcie dobra wspólnego jest raczej gościem w słownikach socjologów niż ich stałym rezydentem.

Socjolodzy używają $\mathrm{w}$ miejsce tego pojęcia innych, mających dłuższą tradycję i pozwalających na ich ściślejsze rozumienie. Mam na myśli zwłaszcza pojęcia więzi społecznych oraz uspołecznienia. Nie chodzi tutaj o banalną konstatację, znaną każdemu studentowi wydziału nauk społecznych, że „człowiek jest istotą społeczną". Zagadnienie to jest dużo bardziej złożone, ale można je sprowadzić do stwierdzenia, że człowiek i społeczeństwo powstali w toku tego samego, stricte społecznego procesu (Kaufmann 2004). Specyfika człowieka jako istoty myślącej wynika z jego społecznego charakteru, „a zatem procesu «uspołecznienia człowieka» $\mathrm{i}$ «uspołecznienia ludzkich społeczności» nie da się wywieść ani $z$ unikalnych cech ludzkiego umysłu, ani z istnienia jakiegoś «instynktu społecznego»" (Marody, Giza-Poleszczuk 2004, s. 93). Stanowi on zawsze efekt istnienia określonej wspólnoty moralnej, która nie jest prostą sumą jednostkowych dążeń i w której to wspólnota wytwarza więzi w złożonym, zmiennym historycznie procesie uspołecznienia. W tym sensie autorki pracy Przemiany więzi społecznych piszą o prymacie socjogenezy nad antropogenezą, czyli o konieczności wzrastania człowieka w społeczeństwie. Nie ma człowieka poza wspólnotą.

Choćby pobieżne omówienie źródeł i istoty procesów uspołecznienia wymagałoby, rzecz jasna, osobnego opracowania. Za ich główną zaletę w porównaniu do dobra wspólnego uważam relatywną łatwość oddzielania zjawisk społecznych od procesów z innych porządków (np. gospodarczych czy teologicznych). Pozwala to uniknąć błędów polegających na błędnym uznaniu tych procesów za tożsame, podczas gdy zachodzi ,jedynie” wzajemny wpływ. Można wręcz powiedzieć, że propozycja Hardta i Negriego jest ufundowana na notorycznym utożsamianiu doniosłej roli procesów społecznych dla gospodarki z czynnościami o ekonomicznym charakterze (na tym oparta jest cała koncepcja pracy biopolitycznej). Analogicznie: katolicka idea praw naturalnych stojąca za filozofią dobra wspólnego Michaela Novaka jest zakorzeniona w transcendencji, którą Émile Durkheim (2010) określał jako przeżywanie wspólnoty. Inaczej mówiąc tam gdzie Novak odwołuje się do Boga, Durkheim widzi efekt zbiorowych emocji i stojącego za nimi aktu powołania społeczeństwa. Tam gdzie Hardt i Negri (a za nimi tłumacze i tłumaczki ich dzieła) są gotowi przypisać Tönniesowskiej Gemeinschaft uniformizujący charakter (przedmowa do Rzecz-pospolitej, s. 45), tam Marody i Giza-Poleszczuk (2004, s. 107) stwierdzają: „dla Toenniesa «jedność» woli naturalnej jest niejako gwarantowna przez wspólne ludziom potrzeby oraz wspólne danej zbiorowości doświadczenia". Tam gdzie filozofowie posługujący się pojęciem dobra wspólnego (w rozważanym tu sensie) widzą

${ }^{17} \mathrm{Nie}$ oznacza to, że dwa pozostałe nie są, choć wydaje się, że należą one do domeny (odpowiednio) filozofii polityki oraz ekonomii. 
wielość składającą się z pojedynczości (lub jak u Novaka z wolnych osób), zapoznawana jest wspólnota uczuć moralnych charakterystyczna i niezbędna dla każdej wspólnoty. Mówiąc ściślej, chodzi o znaną od czasów Comte’a różnorodność środowisk moralnych tworzących współczesne heterogeniczne społeczeństwo, w którym poszczególne kręgi społeczne pozostają w złożonych relacjach. Subtelnie fakt ten opisali polscy klasycy Znaniecki (1974) i Szczurkiewicz (1969), wskazując choćby na zapomniane dziś rozróżnienie na pozycję (świadczenie otrzymywane przez jednostkę) i funkcję (świadczenia, do których jednostka jest zobowiązana) jednostki w danej społeczności.

Reasumując można powiedzieć, że teoria dobra wspólnego rozumianego jako efekt istnienia wspólnoty wiele traci na pobieżnym przyswojeniu dorobku klasycznej i współczesnej socjologii lub zgoła jego braku, poza nawias rozważań usuwając dobrze przepracowane $\mathrm{w}$ tej nauce zagadnienia uspołecznienia, więzi społecznej, wspólnoty, relacji między jednostką a zbiorowością. Wiele uwag filozoficznych traktujących o dobrach wspólnych odnosi się właśnie do tych zagadnień, co gorsza, wielokrotnie modyfikując ich sens lub przywołując je w zbanalizowanej formie, co skutkuje jedynie formalnym przyjęciem realizmu grupowego i realnym opisem wspólnot w kategoriach nominalistycznych lub fikcjalistycznych (Szczurkiewicz 1969). Postulat tych rozważań można więc odczytać następująco: nie więcej dobra wspólnego w socjologii, lecz raczej więcej socjologii w refleksji nad dobrem wspólnym.

\section{BIBLIOGRAFIA}

Benkler Yochai, 2008, Bogactwo sieci. Jak społeczna produkcja zmienia rynek i wolność, tłum. Rafał Próchniak, Wydawnictwo Akademickie i Profesjonalne, Warszawa.

Bollier David, 2014, The Commons. Dobro wspólne dla każdego, tłumaczenie, wydanie i druk: Spółdzielnia Socjalna Faktoria, Zielonka.

Coase Ronald, 1937, The Nature of the Firm, „Economica”, t. 4, s. 386-405.

Connell W. R., 1987, Gender and Power. Society, the Person, and Sexual Politics, Allen \& Unwin-Polity Press, Sydney-Cambridge-Stanford.

Connell W. R., 1995, Masculinities, Polity Press-Allen \& Unwin, Sydney-Cambridge-Berkeley.

Durkheim Emile, 2010, Elementarne formy życia religijnego. System totemiczny w Australii, tłum. Anna Zadrożyńska, Wydawnictwo Naukowe PWN, Warszawa.

Elias Norbert, 2008, Społeczeństwo jednostek, tłum. Janusz Stawiński, Wydawnictwo Naukowe PWN, Warszawa.

Giddens Anthony, 2006, Socjologia, tłum. Alina Szulżycka, PWN, Warszawa.

Granovetter Mark, 1985, Economic Action and Social Structure: The Problem of Embeddedness, „American Journal of Sociology", t. 91, s. 481-510.

Hardin Garrett, 1968, The Tragedy of the Commons, „Science”, t. 162, s. 1243-1248.

Hardt Michael, Negri Antonio, 2004, Multitude, Penguin Books, London.

Hardt Michael, Negri Antonio, 2005, Imperium, tłum. Adam Kołbaniuk, Sergiusz Ślusarski, Wydawnictwo W.A.B, Warszawa.

Hardt Michael, Negri Antonio, 2012, Rzecz-pospolita. Poza własność prywatnq i dobro publiczne, tłum. Praktyka Teoretyczna, Korporacja Ha!art, Kraków. 
Hofmokl Justyna, 2009, Internet jako nowe dobro wspólne, Wydawnictwo Akademickie i Profesjonalne, Warszawa.

Kaufmann Jean-Claude, 2004, Ego: socjologia jednostki, tłum. Krzysztof Wakar, Oficyna Naukowa, Warszawa.

Kochan Jerzy, 2004, Wolność i interpelacja, Wydawnictwo Naukowe Uniwersytetu Szczecińskiego, Szczecin.

Krzysztofek Kazimierz, 2012, Permanentna zmiana? Refleksje o zmianie społecznej w epoce technologii cyfrowych, „Studia Socjologiczne”, nr 207, s. 9-39.

Lemley Mark A., 2004, Property, Intellectual Property, and Free Riding, „John M. Olin Program in Law and Economics Working Paper" No. 291.

Marody Mirosława, Giza-Poleszczuk Anna, 2004, Przemiany więzi społecznych. Zarys teorii zmiany spotecznej, Scholar, Warszawa.

Mika Bartosz, 2013, Cyfrowi kolaboranci-ttumacze-hobbiśsi w spoteczeństwie sieciowym, Wydawnictwo My Book, Szczecin.

Mika Bartosz, 2016, Intellectual Property - Key Factor of Information Age, w: Katarzyna Śledziewska (red), Digital Ecosystems Smart Economy and Innovation, DELab UW, Warszawa.

Novak Michael, 1998, Wolne osoby i dobro wspólne, tłum. Grzegorz Łuczkiewicz, Znak, Kraków.

Ostrom Elinor, 1990, Governing the Commons, The Evolution of Institutions for Collective Action, Cambridge University Press, Cambridge.

Ostrom Elinor, Hess Charlotte, 2003, Ideas Artifacts, and Facilities: Information as a Common-Pool-Resource, „Law and Contemporary Problems”, t. 66, s. 111-146.

Ratajczak Mikołaj, 2010, Wielość: produkcja wspólnotowości, „Praktyka Teoretyczna”, nr 1, s. 159-188.

Ratajczak Mikołaj, 2015, Wprowadzenie do teorii kapitalizmu kognitywnego: kapitalizm kognitywny jako reżim akumulacji, „Praktyka Teoretyczna”, nr 15, s. 57-94.

Roggero Gigi, 2011, Pięć tez o dobru wspólnym, „Praktyka Teoretyczna”, nr 4, s. 69-83.

Szadkowski Krystian, 2015, Uniwersytet jako dobro wspólne. Podstawy krytycznych badań nad szkolnictwem wyższym, Wydawnictwo Naukowe PWN, Warszawa.

Szahaj Andrzej, 2014, Kapitalizm drobnego druku, Książka i Prasa, Warszawa.

Szczurkiewicz Tadeusz, 1969, Niektóre problemy socjologii ogólnej, w: Tadeusz Szczurkiewicz, Studia socjologiczne, Państwowe Wydawnictwo Naukowe, Warszawa.

Sztompka Piotr, 2012, Socjologia. Analiza społeczeństwa, Znak, Kraków.

Walczak-Duraj Danuta, 2014, Wolność gospodarcza a poczucie odpowiedzialności za dobro wspólne, „Annales. Etyka w życiu gospodarczym", t. 17, nr 3, s. 7-17.

Weber Max, 2002, Gospodarka w społeczeństwie. Zarys socjologii rozumiejacej, tłum. Dorota Lachowska, Wydawnictwo Naukowe PWN, Warszawa.

Znaniecki Florian, 1974, Ludzie teraźniejszości a cywilizacja przyszłości, Państwowe Wydawnictwo Naukowe, Warszawa.

\title{
THE COMMON GOOD IN THE EYE OF THE SOCIOLOGIST: A FEW ORDERING REMARKS
}

\author{
Bartosz Mika \\ (University of Gdańsk)
}

Summary

This text can be defined as an attempt to look at the question of the common good through sociological glasses. The author suggests that many of the issues subsumed un- 
der the term "the common good" have already been elucidated and described in detail on the basis of classical and contemporary sociology. If it is assumed that the common good can be understood triply, as (1) a postulate of the social good, (2) materially, as an object of collective ownership, and (3) as an effect of the individual's life in society, then it must be admitted that, at least in the third case, reference to the collected achievements of sociology is necessary in order to describe the common good properly.

\section{Key words / słowa kluczowe}

multitude / wielość, socialization / uspołecznienie, ownership / własność, common-pool resources / dobra wspólnej puli 